\title{
Strategi Bertahan Hidup Nelayan Tour Guide di Masa Pandemi Covid-19
}

\author{
Rino Roy Vandi ${ }^{1}$, Erda Fitriani ${ }^{2}$, Adri Febrianto ${ }^{3}$ \\ ${ }^{1,2}$ Universitas Negeri Padang \\ Email: rinoroy334@gmail.com, erdafitriani@gmail.com
}

\begin{abstract}
Abstrak
Sektor pariwisata termasuk sektor yang mengalami dampak yang signifikan terhadap pandemi Covid 19. Bisnis pariwisata mengalami mati suri yang disebabkan karena pembatasan sosial dan penutupan destinasi pariwisata. Masalah ini menimbulkan pebisnis pariwisata termasuk nelayan tour guide yang mengantar wisatawan ke pulau kehilangan pekerjaan. Penelitian ini bertujuan untuk menjelaskan strategi yang dilakukan nelayan antar jemput pulau (tour guide) Desa Sungai Pisang dalam memenuhi kebutuhan hidup di tengah bencana Pandemic Covid-19. Penelitian dianalisis dengan teori etnosain oleh James P. Spradley. Pendekatan penelitian ini yaitu pendekatan kualitatif dengan tipe penelitian etnografi. Informan dalam penelitian ini berjumlah 15 orang yang terdiri dari 10 orang nelayan tour guide, 1 (satu) orang Ketua PKBM, 1 (satu) orang Lurah Sungai Pisang, 1 (satu) orang Ketua RT dan 2 orang istri nelayan. Hasil penelitian yaitu nelayan selama pandemi covid-19 melakukan adaptasi terhadap perubahan yang terjadi untuk bisa bertahan hidup. Strategi bertahan hidup yang dilakukan oleh nelayan yaitu: (1). Beralih mata pencaharian, pada mata pencaharian yang dulu pernah mereka tekuni dan ada juga yang memulai pekerjaan baru, dan (2). Melakukan pinjaman ke kerabat, koperasi dan pemerintah.
\end{abstract}

Kata kunci: Etnosain, Nelayan Tour Guide, Pandemi Covid-19, Strategi bertahan hidup

Abstract
The tourism sector is one of the sectors that has experienced a significant impact on the Covid 19 pandemic. The tourism business is experiencing torpor due to social restrictions and the closure of tourism destinations. This problem has caused tourism businesses, including tour guide fishermen who take tourists to the island to lose their jobs. This study aims to explain the strategy carried out by island shuttle fishermen (tour guide) in Sungai Pisang Village in meeting the necessities of life in the midst of the Covid-19 Pandemic disaster. The research was analyzed using ethnoscience theory by James P. Spradley. This research approach is a qualitative approach with an ethnographic type of research. There were 15 informants in this study, consisting of 10 fisherman tour guides, 1 (one) Chair of PKBM, 1 (one) head of Sungai Pisang Village Head, 1 (one) Head of RT and 2 fishermen's wives. The results of the study are that fishermen during the COVID-19 pandemic adapt to changes that occur in order to survive. The survival strategies carried out by fishermen are: (1). Switching Livelihoods, to the livelihoods they used to work on and some starting new jobs, and (2). Make loans to relatives, cooperatives and the government.

Keywords: Covid-19 Pandemic, Ethnosience, Survival Strategy, Fisherman Tour Guide

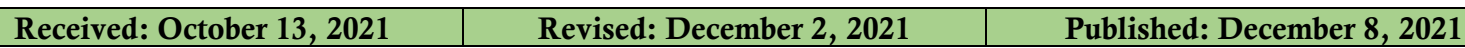

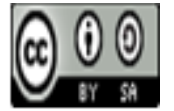




\section{Pendahuluan}

Sumber daya pesisir dan laut merupakan aset yang sangat penting bagi kehidupan masyarakat yang tinggal di sekitarnya. Masyarakat memanfaatkannya untuk berbagai hal dalam memenuhi kebutuhan hidup. Laut tidak hanya menyediakan potensi sumber perikanan yang besar namun, masyarakat juga memanfaatkan laut sebagai media perhubungan, perdagangan, maupun sebagai sumber bahan pangan masyarakat (Jannah, 2016). Nelayan merupakan salah satu bagian dari anggota masyarakat yang mempunyai tingkat kesejahteraan paling rendah (Imron, 2003). Dengan kata lain, masyarakat nelayan adalah masyarakat paling miskin dibanding anggota masyarakat subsisten lainnya. Suatu ironi bagi sebuah negara maritim seperti Indonesia bahwa di tengah kekayaan laut yang begitu besar masyarakat nelayan merupakan golongan masyarakat yang paling miskin (Jannah, 2016).

Apalagi jika dikaji pada saat sekarang ini, dimana semua sektor perekonomian lumpuh akibat Pandemi Covid-19. Terhitung sejak maret 2020 World Health Organization (WHO) mendeklarasikan Corona Virus Disearse 2019 (COVID-19) sebagai pandemi yang telah menyebar secara luar di dunia. Setelah itu, Keputusan Presiden Nomor 12 Tahun 2020 ditetapkan sebagai strategi menanggulangi penyebaran pandemi Covid-19 yang disebutkan sebagai Bencana Nasional. Pandemi Covid-19 dikategorikan sebagai bencana karena tidak hanya sistem kesehatan dan layanan kegawat daruratan diuji secara luar biasa, namun pada kondisi risiko dan juga dampak terhadap kehidupan masyarakat (Muhammad Natsir Kholis, Fraternesi, 2020). Secara umum, Lavell dkk (2020) telah menyajikan tulisannya yang berjudul "The Social Contruction of The Covid-19 Pandemic: Disaster, risk Accumulation and Public Policy" menjelaskan kontruksi sosial dari pandemi ini. Lavell menjelaskan bagaimana Covid-19 dipandang sebagai bencana yang memiliki aspek resiko terhadap masyarakat. Oleh karena itu, pandemi ini memiliki risiko luas dan dampak sosial serta ekonomi di berbagai sektor di Indonesia, salah satunya adalah sektor perikanan dan para aktor di dalamnya (Ratri, 2020).

Dalam Surat Keputusan Gubernur Sumbar Nomor: 180-297-2020 tentang Pemberlakuan Pembatasan Sosial Berskala Besar di Wilayah Provinsi Sumatera Barat Dalam Rangka Percepatan Penanganan Corona Virus Disease 2019 (COVID-19), terhitung dari tanggal 22 April 2020 sampai dengan tanggal 5 Mei 2020 dan dapat diperpanjang berdasarkan rekomendasi gugus tugas percepatan penanganan Covid-19, seluruh wilayah di Sumatera Barat melakukan Pembatasan Sosial Berskala Besar (PSBB) secara serentak. Keadaan semakin dipersulit setelah ditetapkannya Pemberlakuan Pembatasan Kegiatan Masyarakat (PPKM) di Kota Padang pada tanggal 12 Juli 2021. Hal ini secara signifikan mempengaruhi pendapatan masyarakat Desa Sungai Pisang, Kecamatan Bungus Teluk Kabung, Kota Padang, Sumatera Barat. Sebagian besar masyarakat Sungai Pisang menggantungkan hidupnya pada pemasukan di sektor antar jemput wisatawan pulau. Berdasarkan wawancara dengan staf kecamatan Bungus Teluk Kabung, dari 368 Kepala Keluarga (KK), penduduk usia produkif yang ada (15-64) sekitar 60\% masyarakat Desa Sungai Pisang bermata pencarian sebagai nelayan tradisional dan antar jemput wisatawan selebihnya berdagang, bertani dan sebagian lain pegawai negeri (Tiaranita, 2019).

Sebagian masyarakat Desa Sungai Pisang berprofesi sebagai nelayan tour guide atau nelayan antar jemput wisatawan, PSBB yang diterapkan pastinya akan membuat para wisatawan pulau akan terhalang untuk melakukan kunjungan pulau karena peraturan mengharuskan untuk seluruh masyarakat agar tetap di rumah. Ditambah adanya peraturan dari walikota Padang untuk menutup seluruh objek wisata yang ada di Kota Padang tentunya akan semakin mempersulit kehidupan nelayan antar jemput pulau Desa Sungai Pisang.

Di tengah derasnya tuntutan untuk mencukupi kebutuhan hidup, ditambah keadaan yang serba terbatas, tentunya nelayan tetap berusaha gar seluruh kebutuhan primer terpenuhi. Sebagai homo sapiens yang diberikan anugrah otak oleh Tuhan, manusia memiliki berbagai cara agar kebutuhan hidupnya terpenuhi. Oleh karena itu peneliti tertarik meneliti strategi apa yang 
dilakukan nelayan Sungai Pisang agar kebutuhan hidup mereka terpenuhi di tengah pandemi Covid-19 yang melumpuhkan seluruh aspek perekonomian.

Penelitian-penelitian yang sudah dilakukan oleh peneliti lain terkait dengan strategi bertahan hidup nelayan yaitu, Abdul Asis (2019) memberikan deskripsi kehidupan nelayan Pulau Karampuang yang masih menggunakan alat tangkap sederhana dan penghasilannya masih tergolong rendah. Kristianti, Kusai, Bathara (2014) mendeskripsikan strategi bertahan hidup yang dijalankan oleh buruh nelayan di desa Meskom Kabupaten Bengkalis Kabupaten Bengkalis Provinsi Riau.Yeni Marta Diena (2015) di Desa Tasikharjo Kecamatan Kaliori Kabupaten Rembang, menunjukkan bahwa masyarakat nelayan di Desa Tasikharjo kehidupannya sangat bergantung pada kondisi alam. Dari penelitian yang sudah ada, belum banyak penelitian yang mengkaji kehidupan nelayan di era pandemi Covid 19, khususnya nelayan tour guide di destinasi pariwisata. Hal ini menjadi novelty dari penelitian yang dilakukan.

Kondisi lingkungan yang berubah karena adanya pandemic Covid 19, pembatasan sosial, larangan ke luar rumah, menyebabkan wisatawan tidak berkunjung ke lokasi wisata. Desa Sungai Pisang merupakan daerah yang menyediakan sarana bagi pengunjung yang ingin berkunjung ke pulau untuk berwisata atau pun untuk memancing. Akan tetapi karena pandemic, maka wisatawan yang datang ke Desa Sungai Pisang menjadi tidak ada. Di sisi lain, nelayan harus tetap menyediakan kebutuhan utama bagi anggota keluarga terutama makanan. Kondisi ini menyebabkan nelayan tour guide melakukan strategi-strategu agar tetap dapat memenuhi kebutuhan hidup rumah tangganya. Strategi adaptasi maksudnya sebuah pilihan tindakan yang bersifat rasional dan efektif sesuai dengan konteks lingkungan sosial ekonomi, serta ekologi dimana penduduk tersebut tinggal. Pemilihan tindakan yang kontekstual tersebut dimaksudkan untuk mengalokasikan sumberdaya yang tersedia di lingkungan guna mengatasi tekanan-tekanan sosialekonomi, agarmereka tetap dapat melangsungkan hidupnya (Kusnadi, 2000:7). Dalam hal ini akan diungkap sistem pengetahuan yang dimiliki oleh nelayan dengan latar belakang budaya dan adaptasi terhadap lingkungan yang dimiliki, sehingga melahirkan berbagai strategi untuk bertahan hidup.

Ethnoscience adalah "system of knowledge and cognittion typical of given culture". Penekanannya di sini adalah pada sistem pengetahuan masyarakat, yang merupakan pengetahuan yang khas dari suatu masyarakat, dan berbeda dengan sistem pengetahuan masyarakat lain. Mengingat pengetahuan ini sangat luas lingkupnya, bisa menyangkut berbagai macam hal, maka dalam penelitiannya seorang ahli antropologi biasanya tidak akan menggali semua isi pengetahuan yang ada, melainkan hanya pengetahuan tentang hal-hal tertentu saja dalam kehidupan atau dunia mereka yang dia minati. Etnosain menekankan bahwa data yang disodorkan adalah data kognitif (mental codes).

Orang antropologi kognitif ini berasumsi bahwa setiap masyarakat mempunyai sistem yang unik dalam mempersiapkan dan mengorganisasikan fenomena material, seperti bendabenda, kejadian, perilaku, dan emosi. Etnosains mendeskripsikan makna-makna yang hidup dalam masyarakat atau dasar makna yang diberikan oleh orang-orang yang diteliti. Menurut Malinowski "to grasp the native's point of view, his relation to life, to realize his vision of his world" menemukan makna dari suatu kebudayaan melalui klasifikasi lokal yang dibuat masyarakat dari suatu kebudayaan. Kebudayaan sebagai pengetahuan dan manusia sebagai makhluk sosial, dipakai untuk memahami dan menginterpretasikan lingkungan dan pengalaman, tidak lain karena semua itu akan mempengaruhi kelakuannya. Mengingat pengetahuan ini sangat luas lingkupnya, bisa menyangkut berbagai macam hal, maka dalam penelitiannya seorang ahli antropologi biasanya tidak akan menggali semua isi pengetahuan yang ada, melainkan hanya pengetahuan tentang hal-hal tertentu saja dalam kehidupan atau dunia mereka, yang dia minati (Ahimsa, 1985). 


\section{Metode Penelitian}

Penelitian ini dilakukan dengan pendekatan kualitatif. Penelitian kualitatif bermaksud untuk menghasilkan data deskriptif berupa kata-kata tertulis atau lisan dari orang-orang, dan perilaku yang dapat diamati. Penggunaan Pendekatan Kualitatif dikarenakan peneliti merasa bahwa permasalahan yang akan diteliti dinamis dan menyangkut pada setiap tindakan masyarakat (Sugiyono, 2017). Tipe penelitian ini termasuk pada penelitian etnografi. Bagian penting dari etnografi adalah penelitian ini mengggunakan pengamatan terlibat (participant observation). Pengamatan terlibat sebenarnya bukan merupakan metode tunggal, karena sebenarnya pengamatan terlibat merupakan strategi lapangan yang secara simultan memadukan analisis dokumen, wawancara mendalam, dan teknik-teknik lain (Sudarsono, 2017).

Peneliti memilih pendekatan ini karena dianggap mampu membantu peneliti dalam melihat fenomena sosial yang ada di lingkungan masyarakat nelayan Desa Sungai Pisang secara dekat dan mendalam. Tipe penelitian etnografi merujuk tindakan-tindakan yang dilakukan masyarakat untuk mengatasi permasalahan sesuai dengan pengetahuan yang mereka miliki. Kemudian peneliti akan mengambil kesimpulan emik yang nantinya peneliti sampaikan pada kesimpulan pembahasan penelitian (Winarno, 2015). Konsep-konsep pokok dalam etnosain diantaranya adalah klasifikasi atau tipologi, yakni bagaimana peneliti menjelaskan dunianya dengan cara membuat kategorisasi-kategorisasi tertentu terhadap semua hal yang ada di sekitarnya, yang diketahui, dan pernah dialami. Klasifikasi ini terkadang menggunakan istilahistilah lokal dan lengkap dengan deskripsinya (Anwar, 2018). Informan penelitian dipilih secara sengaja (purposive sampling), bertujuan untuk menghasilkan sampel yang secara logis dapat dianggap mewakili populasi. Jumlah informan keseluruhan dalam penelitian 15 orang, yang terdiri dari 10 orang nelayan tour guide, 1 (satu) orang Ketua PKBM, 1 (satu) orang Lurah Sungai Pisang, 1 (satu) orang Ketua RT dan 2 orang istri nelayan.

Teknik pengumpulan data yang digunakan dalam penelitian ini adalah observasi partisipasi, wawancara mendalam (in-depth interview), dan studi dokumen. Wawancaramendalam (in-depth interview) adalah proses memperoleh keterangan untuk tujuan penelitian dengan cara tanya jawab sambil bertatap muka antara pewawancara dengan informan, dengan atau tanpa menggunakan pedoman (guide) wawancara dimana pewawancara dan informan terlibat dalam kehidupan sosial yang relatif lama (Sutopo 2006: 72). Studi dokumentasi dilakukan untuk memperkuat data yang telah didapatkan dari observasi dan wawancara atau sebagai sumber baru yang mendukung dan berhubungan dengan permasalahan yang diteliti. Hasil penelitian dari observasi dan wawancara akan lebih dapat dipercaya jika didukung oleh studi dokumen. Dalam menguji keabsahan data dalam penelitian, peneliti menggunakan triangulasi sumber. Triangulasi sumber adalah pengambilan data dari beberapa sumber yang berbeda dengan menggunakan teknik yang sama. Dalam melakukan penelitian, peneliti mengumpulkan data dengan menggunakan pertanyaan yang sama (Sugiyono, 2006). Dalam hal ini peneliti datang melakukan field work langsung ke tempat penelitian, yaitu Desa Sungai Pisang Kelurahan Teluk Kabung Selatan. Peneliti mengamati lingkungan sekitar serta aktivitas masyarakat yang tinggal di Desa Sungai Pisang terutama nelayan tour guide. Selain itu, peneliti juga ikut aktif dalam kegiatan yang dilakukan masyarakat. Serta beradaptasi dengan kebiasaan masyarakat sehari-hari sambil mendengarkan apa saja yang masyarakat bicarakan.

\section{Hasil dan Pembahasan}

\section{Deskripsi Desa Sungai Pisang}

Desa Sungai Pisang merupakan Kelurahan Teluk Kabung Selatan yang berada di Kecamatan Bungus Teluk Kabung Kota Padang Sumatera Barat. Desa ini berbatasan langsung dengan Nagari Sungai Pinang Koto XI Tarusan fPesisir Selatan. Desa Sungai Pisang memiliki luas 9,14 Ha dengan jarak dari Kecamatan $10 \mathrm{Km}$ dan $32 \mathrm{Km}$ dari Kota Padang. Daerah ini memiliki kontur tanah berbukit serta berhadapan langsung dengan pesisir pantai. Dari sisi 
pariwisata, Desa Sungai Pisang terletak di daerah Teluk Bungus yang indah dan strategis serta dekat banyak pulau kecil. Banyak masyarakat setempat menyediakan jasa transportasi kapal menuju pulau-pulau di sekitar Sungai Pisang. Pulau Pasumpahan dan Sirandah merupakan dua pulau yang telah dikelola dengan baik sebagai tujuan wisata. Selain itu terdapat pulau Pamutusan, Suwarnadwipa, Pagang, Sikuai, Setan dan lainnya yang dapat diakses dari Sungai Pisang.

Jumlah penduduk Desa Sungai Pisang berdasarkan data Badan Pusat Statistik (BPS) Kota Padang 07 Mei 2021 berjumlah 4.311 jiwa, dibentuk oleh $654 \mathrm{KK}$ dengan persentase jumlah penduduk laki-laki 2.222 jiwa sedangkan jumlah penduduk perempuan 2.089 jiwa. Dari sisi pendidikan, pada umumnya pendidikan masyarakat masih rendah. Namun jika dilihat dari 2 tahun belakangan telah terjadi kenaikan kesadaran pendidikan oleh masyarakat Desa Sungai Pisang. Telah terjadi peningkatan angka partisipasi sekolah dibandingkan tahun 2019 pada usia 13-18 tahun sekitar 0,77 persen. Mata pencaharian utama masyarakat desa adalah sebagai nelayan. Nelayan Sungai Pisang dibedakan atas 2 pembagian pekerjaan yaitu nelayan tradisional dan nelayan antar jemput wisatawan atau nelayan tour guide. Berdasarkan wawancara dengan ketua kelompok nelayan Gabuo Sepakat bahwa total jumlah nelayan sebanyak 76 orang yang terdiri dari 32 anggota yang memiliki boat, 30 anggota tumpangan, 8 anggota bagan dan 6 anggota nelayan penangkap ikan. Desa Sungai Pisang memiliki kapal berjumlah 56 unit dengan rincian 4 unit kapal bagan yang dinahkodai oleh kelompok nelayan Gabuo Sepakat Sungai Pisang, 32 kapal boat tour guide yang biasa digunakan untuk mengantar maupun menjemput wisatawan yang berkunjung. Lima unit kapal penangkap ikan yang masih aktif digunakan nelayan tradisional untuk menangkap ikan musiman. Sembilan unit kapal Robin yang digunakan nelayan untuk menjaring pukat di sekitaran pesisir pantai Sungai Pisang.

\section{Pendapatan Nelayan Sebelum dan Sesudah Pandemi Covid-19}

Dari hasil wawancara yang dilakukan terhadap beberapa nelayan tour guide, rata rata nelayan mengalami penurunan pendapatan. Penurunan pendapatan ini diakibatkan oleh terhambatnya akses masuk wisatawan untuk berkunjung ke pulau. Penurunan pendapatan nelayan tersebut dapat dilihat pada tabel dibawah ini:

Tabel 1. Rincian Pendapatan Nelayan Tour Guide Desa Sungai Pisang Sebelum dan Sesudah Pandemi Covid-19

\begin{tabular}{|c|c|c|c|c|}
\hline \multirow[t]{2}{*}{ No. } & \multirow[t]{2}{*}{ Nama Nelayan } & \multirow[t]{2}{*}{ Usia } & \multicolumn{2}{|c|}{ Pendapatan (per 1 bulan) } \\
\hline & & & Sebelum & Sesudah \\
\hline 1 & Nofriyono & 35 Tahun & \pm Rp. 8.000 .000 & - \\
\hline 2. & Fahmi & 36 Tahun & \pm Rp. 11.000 .000 & \pm Rp. 1.000 .000 \\
\hline 3. & Ijek & 36 Tahun & \pm Rp. 6.000 .000 & - \\
\hline 4. & Bustami & 47 Tahun & \pm Rp. 8.000 .000 & - \\
\hline 5. & Oki & 26 Tahun & \pm Rp. 6.000 .000 & - \\
\hline 6. & Agus & 34 Tahun & \pm Rp. 8.000 .000 & - \\
\hline 7. & Rodi & 24 Tahun & \pm Rp. 9.000 .0000 & \pm Rp. 1.000 .000 \\
\hline 8. & Andi & 24 Tahun & \pm Rp. 6.0000 .000 & - \\
\hline 9. & Desra & 25 Tahun & \pm Rp. 6.000 .000 & - \\
\hline \multirow[t]{3}{*}{10.} & Degi & 33 Tahun & \pm Rp. 6.000 .000 & - \\
\hline & Rata-Rata & & \pm Rp. 7.400 .000 & \pm Rp. 200.000 \\
\hline & Selisih & & $\pm \mathrm{Rp}$ & 000 \\
\hline
\end{tabular}

Sumber: Wawancara dengan Nelayan Tour Guide Desa Sungai Pisang, data diolah peneliti 
Pendapatan nelayan di masa pandemik terhitung dari bulan Maret 2020 menggalami penurunan. Sebelum Pandemi Covid-19 nelayan tour guide Desa Sungai Pisang Berpendapatan \pm Rp. 7.400.000 Perbulan. Namun Penurunan drastis terjadi pada masa Pandemi Covid-19 yaitu \pm Rp. 2.000.000. bahkan tidak ada sama sekali. Hal ini disebabkan karena adanya PSBB, yang tidak membolehkan masyarakat beraktivitas di luar rumah dan penutupan destinasi wisata.

\section{Strategi Bertahan Hidup Nelayan Tour Guide}

\section{Beralih Mata Pencarian}

Peralihan mata pencaharian terjadi apabila pendapatan masyarakat rendah disertai dengan kerugian yang dialami membawa efek domino bagi aspek lain, seperti ketidakmampuan masyarakat dalam memenuhi kebutuhan hidup sehari-hari, tidak mampu mendapatkan akses pada sektor kesehatan dan pendidikan, dan lain sebagainya (Septiana, 2013). Sekitar Satu Tahun belakangan keadaan ekonomi masyarakat Indonesia sedang diuji oleh wabah pandemi Covid-19. Keadaan yang tidak memperbolehkan nelayan tour guide untuk bekerja menyebabkan nelayan tour guide Sungai Pisang tidak bisa mencukupi kebutuhan hidup keluarganya. Namun untuk menyokong pendapatan, ada strategi yang mereka lakukan dalam memenuhi kebutuhan hidup, yaitu dengan beralih mata pencaharian. Peralihan yang terjadi pada masyarakat nelayan tour guide dibagi dua yaitu:

\section{Beralih ke Mata Pencaharian Lama}

Masyarakat Sungai Pisang merupakan masyarakat nelayan. Mereka hidup dari menangkap ikan di laut. Pekerjaan sebagai nelayan tour guide ada semenjak pariwisata berkembang di Sumatera Barat. Artinya pekerjaan menangkap ikan, menjaring ikan, mamukek merupakan pekerjaan yang sudah sejak dahulu dilakukan oleh nenek moyang orang Sungai Pisang. Selain itu lingkungan Desa Sungai Pisang juga subur, terdapat sawah dan ladang, sehingga masyarakat dari dahulu juga bekerja di sawah menanam padi dan di hutan mereka juga mengambil hasil hutan seperti kayu dan buah. Berdasarkan hasil wawancara dan observasi masayarakat nelayan tour guide beralih pada mata pencaharian yang dulu mereka lakukan seperti, bertani, berkebun, menangkap ikan dan ke hutan mencari kayu. Peralihan ini terjadi karena dulunya mereka memiliki kemampuan di bidang pekerjaan tersebut, dan sekarang untuk memenuhi kebutuhan hidup mereka menekuninya lagi. Peralihan tersebut antara lain, mencari kayu ke hutan dan berternak itik dan menjaring ikan.

\section{Mencari Kayu ke Hutan}

Tantangan demi tantangan yang dihadapi Nelayan Tour Guide Sungai Pisang dalam memenuhi kebutuhan hidup ditengah Pandemi Covid-19 membuat mereka kembali menggeluti pekerjaan yang dulunya mereka tinggalkan. Pernyataan tersebut sejalan dengan hasil wawancara bersama Ketua Kelompok Nelayan Gabuo Sepakat bapak Andrial (Da Apuak) pada Hari Sabtu Tanggal 7 Agustus 2021 Menyatakan:

"Kalau hari biaso kami bisa berpendapatan 5-6 juta perbulannyo, apo lagi hari-hari gadang, itu bisa sampai 10-15 juta perbulannyo. Kini samanjak ado PPKM patang kami para nelayan indak bisa mancari karano wisatawan indak ado dan pulau pun ditutuik. Jadi kini ko apo nan dapek se di karajoan lai, kalo ambo pribadi kini karajo ka rimbo mancari kayu, bagi nelayan yang ado jariang, nyo maelo pukek, bagi yang bisa manyinso nyo ka rimbo mancari kayu, atau ado juo yang manangkok kapitiang, bagi yang ado tabungan nyo bukak usaho taranak baru, bahkan ado juo nelayan yang baliak baladang

Artinya:

"Kalau hari biasa kami bisa berpendapatan 5-6 juta perbulannya, apalagi hari-hari besar kami bisa mendapatkan 10-15 juta perbulannya. Semenjak PPKM diterapkan kami para nelayan tidak bisa bekerja dikarenakan wisatawan tidak ada yang berkunjung dan objek wisata pulau ditutup. Jadi untuk memenuhi kebutuhan hidup,

Culture \& Society: Journal of Anthropological Research Vol. 3, No. 1, Th. 2021 
saya pribadi pada saat ini bekerja mencari kayu dihutan, bagi nelayan yang memiliki jaring mereka bisa menebar jaring pukat, bagi yang memiliki keterampilan memotong kayu mereka bisa ke hutan untuk mencari kayu, atau ada juga yang menangkap kepiting, bagi mereka yang ada tabungan mereka membuka usaha ternak, bahkan ada juga nelayan yang kembali berkebun"

Berdasarkan hasil wawancara menyampaikan bahwa untuk memenuhi kebutuhan hidup dimasa pandemi Covid-19 nelayan tour guide Sungai Pisang melakukan berbagai macam pekerjaaan untuk memenuhi kebutuhan hidupnya, seperti kembali menjaring ikan/mamukek, kehutan mencari kayu, menangkap kepiting, membuka usaha ternak, bahkan ada nelayan yang kembali berkebun. Bapak Andrial sendiri mengakui bahwa sekarang beliau bekerja sebagai pencari kayu di hutan.

\title{
Beternak Itik, mencari kayu ke hutan
}

Untuk menunjang kebutuhan hidup nelayan tour guide beralih mata pencaharian sebagai peternak itik, pernyataan tersebut peneliti peroleh pada saat wawancara dengan bapak Bustami, beliau menyampaikan:

"Salagi manunggu korona ko salasai, ambo bataranak itiak, ituang-ituang untuak balanjo anak samo pambali rokok, biasonyo ado tambahan penghasilan lain dari bini, kini dek bini lah maningga tapaso ambo mancaro sorang lai, kini lai lah sakali batalua bisa manjua 20 talua itiak ka pasa gauang, sambia manunggu korona ko hilang iko se usaho ambo dulu"

\begin{abstract}
Artinya:
"Selagi menunggu pandemic selesai, saya berternak itik, hitung-hitung untuk menambah uang jajan anak dan pembeli rokok, biasanya ada tambahan penghasilan lain dari istri, sekarang istri sudah meninggal, ya terpaksa saya mencari sendiri, sekarang Alhamdulillah sekali menjual bisa 20 telur itik ke pasar gauang, sambil menunggu pandemic berakhir ini usaha yang saya lakuka".
\end{abstract}

Berdasarkan hasil wawancara informan menyampaikan bahwa pada saat pandemi ini untuk memenuhi kebutuhan hidupnya beliau beternak itik. Biasanya dalam setiap hari beliau menghasilkan 20 telur itik yang dijual di pasar terdekat. Dari usaha tersebut bapak bustami mengakui bisa memenuhi kebutuhan hidup mereka.

\section{Manjariang dan Mamukek}

Untuk memenuhi kebutuhan hidup ditengah pandemic covid-19 nelayan tour guide Sungai Pisang kembali menekuni pekerjaan yang dulu pernah mereka lakukan seperti manjariang dan mamukek, pernyataan tersebut peneliti temukan pada saat wawancara dengan bapak Yono, beliau menyampaikan:

"...dek jariang lai yo ambo satiok sore manjariang kapitiang, dek lah lamo masyarakai disiko indak manjariang, kapitiang samakin banyak, dalam samalam kami bisa mandapekan 20 Kg, ituang2 bisa untuak bali bareh..."

Artinya:

“... Karena saya ada jaring, saya setiap sore menjaring kapitiang, karena masyarakat jarang menjaring kepiting, kepiting hasil tangkapan kami selaku banyak, bahkan dalam sehari kami bisa mendapatkan $20 \mathrm{Kg}$ kepiting, itung-itung bisa untuk membeli beras di rumah..." 
Berdasarkan pernyataan informan sebagai penjaring kepiting, karena orang jarang menjaring, hasil tangkapan beliau perhari bisa mencapai $20 \mathrm{Kg}$, populasi kepiting begitu banyak karena jarangnya nelayan menangkap kepiting, oleh karena itu dengan menangkap kepiting, bapak Yono bisa memenuhi kebutuhan hidup keluarganya.

\title{
Beralih ke Mata Pencaharian Baru
}

Peralihan pada mata pencaharian baru antara lain yaitu, menjual sulaman secara online, menjual ikan hias melalui media sosial dan membuka usaha konter kecil-kecilan. Peralihan atau perpindahan tersebut terjadi melalui proses belajar dari sistem pengetahuan yang mereka miliki dan pengalaman yang pernah mereka dapatkan.

\section{Menjual Sulaman dan Tenunan Secara Online}

Untuk memenuhi kebutuhan hidup ditengah Pandemi Covid-19 berbagai macam usaha dilakukan oleh masyarakat nelayan Tour Guide Sungai Pisang. Tidak hanya beralih mata pencarian secara Ofline, mereka juga beradaptasi dengan pekerjaan-pekerjaan yang dijalankan secara Online, pernyataan tersebut disampaikan oleh ibuk Kasmawati (Ketua PKBM Pintu Ilmu) pada wawancara Hari Rabu Tanggal 11 Agustus 2021 beliau menyampaikan:

"Banyak dari Nelayan lah mulai kasawah, mangubalo itiak, maelo kayu ka rimbo atau baladang. Sebagian yang manumpang (nelayan tour guide yang tidak memiliki kapal) banyak juo yang manjariang atau mamukek. Kalo untuak ART di PKBM ko, kami untuak memenuhi kebutuhan atau setidaknyo manambah balanjo, PKBM ado Program Wirausaha Kreatif seperti sulaman, tenunan yang dibuek oleh Anggota PKBM, nantinyo Produk iko akan dipasarkan secara Onlinedii facebook, WhatsApp. Semenjak pandemiko satiok ado kegiatan maupun pelatihan Alhamdulillah Produk kami laku. Itulah yang ART harokan untuk manambah balanjo keluarganyo"

\begin{abstract}
Artinya:
"Banyak dari nelayan yang kembali bertani, berternak itik, mencari kayu ke hutan, sebagian nelayan yang tidak memiliki Kapal beralih menjadi nelayan menjaring ikan. Mereka memenuhi kebutuhan atau setidaknya mengurangi beban suami. PKBM menyediakan Program Wirausaha Kreatif seperti membuat produk sulaman, tenunan yang nantinya Produk ini akan dipasarkan secara online melalui Facebook dan WhatsApp. Semenjak Pandemi setiap ada kegiatan maupun pelatihan, Alhamdulillah Produk kami laku. Itulah yang ART harapkan untuk mengurangi tanggungan suami."
\end{abstract}

Dari pernyataan yang disampaikan informan bahwa peralihan mata pencaharian juga dilakukan secara Online melalui produk sulaman emas dan tenunan yang dijual melalui Facebook dan WhatsApp dapat membantu ara ibu rumah tangga dalam memenuhi kebutuhan hidup keluarganya. Para ibu rumah tangga mengambil peran agar kecukupan hidup terpenuhi. Mereka semakin antusias dalam mengikuti kegiatan PKBM Pintu Ilmu karena dari sana mereka bisa mendapatkan tambahan penghasilan

\section{Menjual Ikan Hias Melalui Media Sosial}

Untuk menunjang kebutuhan hidup di tengah pandemi covid-19, nelayan tour guide melakukan berbagi cara. Seperti yang peneliti temukan pada saat wawancara dengan Bapak Ijek pada hari Kamis Tanggal 12 Agustus 2021:

"Dalam Kondisi mode ko, indak banyak yang bisa dilakukan do, ambo sebagai urang sumando yang ndak punyo bot iyo maraso payah juo. Dek tamu ndak ado kapulau, ambo dek dulu pernah bataranak ikan cupang, kini ambo cubo untuk batarak baliak. Ambo memulai 
taranak Ikan Cupang Ko lah Jalan 8 Bulan Selagi ikan cupang musim, lai bisalah untuk marasokan tungku rumah."

Artinya:

"Dalam kondisi seperti ini, tidak banyak yang bisa dilakukan, saya sebagai orang sumando yang tidak memiliki bot pribadi merasa sangat kesulitan, namun saya dulu pernah memiliki pengalaman budidaya ikan, sekarang saya kembali mencoba budidaya ikan Cupang, pekerjaan ini sudah 8 bulan saya tekuni, dan kebetulan ikan Cupang lagi musim. Dengan budidaya ini kebutuhan rumah tangga bisa tercukupi."

Pada saat wawancara bapak Ijek menyampaikan bahwa sangat kesulitan di tengah kondisi sekarang ini. Ia memulai usaha baru ditengah Pandemi Covid-19, yaitu usaha budidaya ikan Cupang. Beliau menekuni Usaha ini sudah 8 bulan. Beliau menyampaikan pada masa pandemi daya beli Ikan Cupang begitu tinggi sehingga dengan hasil itu beliau bisa memenuhi kebutuhan rumah tangga.

\section{Membuka Konter Kecil-kecilan}

Dalam mencukupi kebutuhan hidup di tengah pandemic Covid-19 nelayan tour guide mencari peluang agar bisa memperoleh penghasilan. Hal tersebut sesuai dengan pernyataan bapak Degi sebagai berikut:

"Dek pandapekan indak manantu, kini ambo samo bini ambo untuak samantaro mambuka usaho baru manggaleh voucer atau konter kecil-kecilan lah, dek anak baru ciek untuak kini karajo kayak iko lai lah bisa untuak hiduik, ciek lai konter di sungai pisang ko alun pulo lai lai kan."

Artinya:

"Karena pendapatan tidak menentu, sekarang saya dan istri untuk sementara membuka usaha baru menjual voucher atau konter kecil-kecilan, mumpung anak masih satu untuk sekarang bisalah untuk menafkahi istri, untuk peluang cukup besar karena konter di sungai pisang ini baru satu".

Berdasarkan wawancara diketahui bahwa selama pandemi istri memulai usaha baru dengan membuka konter kecil-kecilan. Sehingga dapat menambah pendapatan untuk pemenuhan kebutuhan rumah tangga.

\section{Melakukan Pinjaman ke Kerabat, Koperasi dan Pemerintah}

Pinjaman adalah suatu jenis hutang yang disediakan oleh individu atau lembaga keuangan dimana disediakan sejumlah uang yang akan dipinjamkan kepada debitur (Asis, 2019). Pinjaman adalah jenis hutang yang dapat melibatkan semua jenis benda berwujud walaupun biasanya lebih sering diidentikkan dengan pinjaman moneter. Seperti halnya instrumen hutang lainnya, suatu pinjaman memerlukan distribusi ulang aset keuangan seiring waktu antara peminjam (terhutang) dan penghutang (Kristianti, Kusai, 2014). Dalam upaya memenuhi kebutuhan hidup masyarakata nelayan tour guide pada masa pandemi Covid-19 melakukan pinjaman merupakan solusi agar mereka bisa memenuhi kebutuhan hidup. Hal ini terlihat dari hasil wawancara dengan Bapak Zulfahmi pada Hari Rabu Tanggal 11 Agustus 2021, Bapak Zulfahmi selaku Ketua Lurah menyampaikan:

"Sebagai badan pemerintahan kami selalu berupaya semaksimal mungkin dalam membantu menyesejahterakan masyarakat, disituasi yang seperti ini kami mengutamakan penyaluran bantuan kepada masyarakat. Baik itu dari swasta maupun dari pemerintahan, setiap informasi yang ada kami selalu dengan cepat menyampaikan kepada masyarakat, untuk meningkatkan pendapatan masyarakat 
ditengan pandemic covid, saya pribadi secara terbuka menyampaikan bahwa ada dana desa yang bisa masyarakat pinjam. Program itu dikenal dengan BUMDES Simpan Pinjam untuk mempermudah masyarakat, pemerintah menyederhanakan persyaratan untuk meminjam, desa juga memiliki Program PNPM, yang mana nantinya program ini memiliki turunan Program SPP, semenjak pendapatan nelayan menurun banyak ibu-ibu yang melakukan pinjaman ke desa melalui Program SPP. Keterangan yang kami dapat bahwa ibu-ibu ini meminjam untuk modal usaha baru suaminya. Disisi lain kami juga mempermudah masyarakat, bahkan kami selalu mengsosialisasikan bahwa ada BUMDES untuk masyarakat meminjam"

Berdasarkan hasil wawancara dengan Bapak Zulfahmi ia menyampaikan bahwa selama masa pandemi telah terjadi peningkatan peminjaman masyarakat melalui BUMDES Badan Usaha Milik desa. Peminjaman tersebut dilakukan melalui Program Nasional Pemberdayaan Masyarakat Mandiri Nasional (PNPM). Bapak Zulfahmi juga menyampaikan bahwa pemerintah desa memiliki satu program yang diberi nama SPP (Simpan Pinjam Untuk Kelompok Perempuan), yang mana program ini disalurkan untuk ibu-ibu yang memerlukan biaya untuk modal usaha. Beliau juga menyampaikan dari hasil sosialisasi yang dilaksanakan, telah terjadi peningkatan peminjaman SPP pada masa pandemi.

Tidak hanya ke pemerintah nagari, masyarakat nelayan juga melakukan pinjaman ke Koperasi Simpan pinjam, Hal ini peneliti temukan pada saat wawancara dengan bapak Bustami pada Hari Saptu Tanggal 7 Agustus 2021, beliau menyampaikan:

"Salagi manunggu korona ko salasai, ambo bataranak itiak, ituang-ituang untuak balanjo anak samo pambali rokok, biasonyo ado tambahan penghasilan lain dari bini, kini dek bini lah maningga tapaso ambo mancaro sorang lai, untuak mamulai usaho itiak ko ambo maminjam Koperasi Madani, dari situ ambo bali Itiak, kini lai lah sakali batalua bisa manjua 20 talua itiak ka pasa gauang, sambia manunggu korona ko hilang iko se usaho ambo dulu"

Artinya:

"Selagi menunggu korona hilang, saya mencoba untuk berternak Itik, hitung-hitung untuk keperluan anak dan membeli rokok, biasanya ada tambahan penghasilan dari istri, sekarang karena istri sudah meninggal terpaksa saya bekerja sendiri, untuk memulai usaha bertenak Itik ini saya meminjam modal ke Koperasi Madani, dari situlah saya membeli Itik, sekarang saya bisa menjual telur Itiak setiap pagi 20 Buah ke pasar, sambil menunggu korona hilang, pekerjaan ini akan saya tekuni"

Dari hasil wawancara dengan Bapak Bustami beliau menjelaskan bahwa sembari menunggu Pandemi berakhir beliau memulai usaha baru yaitu bertenak itik petelur. Beliau juga menyampaikan telah meminjam modal Ke Koperasi untuk memulai usahanya. Sekarang dengan pekerjaan barunya, Bapak Bustami bisa menjual 20 butir telur Itik setiap pagi ke Pasar. Ungkapan yang sama juga disampaiakan pada saat wawancara dengan bapak Degi pada hari Minggu Tanggal 8 Agustus 2021 sebagai berikut:

"Dek pandapekan indak manantu, kini ambo samo bini ambo untuak samantaro mambuka usaho baru manggaleh voucer atau konter kecil-kecilan lah, dulu untuak modal partamo iyo dipinjaman dek induak samang, dek induak samang ko lai elok, ambo mangantinyo ndak samo kepiang do, cukuik satiok sore maantaan anak bagan ka kapa se nyo, itupun salamo sabulan nyo selain itu beko kalo ado lauak dari bagan ambo dapek pulo, sadang kini Alhamdulillah dek sadoalahnyo online lai banyak jua bali kami, kalo sore bini ambo manjua gorengan, dek anak baru ciek untuak kini karajo kayak iko lai lah bisa untuak hiduik, ciek lai konter di sungai pisang ko alun pulo lai lai kan".

Culture \& Society: Journal of Anthropological Research Vol. 3, No. 1, Th. 2021 


\begin{abstract}
Artinya:
"Karena pendapatan tidak menentu sekarang saya dengan istri membuka konter kecil-kecilan, dulu untuk modal awal, saya meminjam ke Bos (Orang pemilik Kapal Penangkap Ikan/Bagan), karena bos saya baik, utang yang saya pinjam diganti dengan cara mengantarkan anak buah kapal setiap sore, itu saya lakukan selama sebulan, selain itu kalo ada ikan saya juga dikasih, sekarang Alhamdulillah karena semuanya online banyak jual beli kami, sore istri saya juga berjualan gorengan, anak baru satu jadi untuk sekarang karajo seperti ini cukup menghidupi keluarga, rencananya saya akan memperluas usaha ini karena konter belum ada di sungai pisang".
\end{abstract}

Berdasarkan wawancara dengan bapak Degi beliau menyampaikan bahwa selama pandemi ia bersama istrinya memulai usaha baru dengan membuka konter kecil-kecilan. Beliau mendapatkan modal dari bos kapal yang beliau kenal. Uniknya karena kedekatan beliau mengganti pinjaman tersebut tidak dengan uang, melainkan dengan jasa yang beliau berikan yaitu mengantarkan anak buah kapal setiap sore ke bagan.

Dari hasil wawancara yang peneliti lakukan terhadap beberapa nelayan tour guide di Desa Sungai Pisang, tampak jelas bahwa adanya peningkatan pinjaman baik itu oleh pemerintah dengan nelayan, nelayan dengan kerabat maupun nelayan tour guide dengan Koperasi Simpan Pinjam. Hubungan itu merujuk pada azas saling menguntungkan. Usaha tersebut mereka lakukan sebagai ganti kecilnya pendapatan dari pekerjaan sebagai nelayan tour guide. Hubungan itu terjadi dalam bentuk Strategi untuk memenuhi kebutuhan ditengah masa pandemi Covid-19.

\title{
Analisis Etnosain pada Strategi Nelayan Tuor Guide dalam Memenuhi Ketuhuhan Hidup di Tengah Bencana Pandemi Covid-19
}

Hasil temuan tersebut dianalisi secara tematik, yang mana Analisis tematik ertnografi digunakan dalam upaya mendeskripsikan secara menyeluruh karateristik kultural yang memengaruhi perilaku sosial individu. Dari hasil observasi yang telah dilakukan, peneliti memperoleh 4 temuan yang mana dari 4 temuan ini peneliti menetapkan 3 temuan yang sesuai dengan tujuan penelitian.

Temuan data tersebut yaitu: (1) terjadinya peralihan mata pencaharian dalam kehidupan masyarakat nelayan tour guide Sungai Pisang. Peralihan mata pencaharian adalah proses peralihan atau perpindahan mata pencaharian. Perpindahan ini terjadi apabila pendapatan masyarakat rendah disertai dengan kerugian yang dialami membawa efek domino bagi aspek lain, seperti ketidakmampuan masyarakat dalam memenuhi kebutuhan hidup sehari-hari, tidak mampu mendapatkan akses pada sektor kesehatan dan pendidikan, dan lain sebagainya (Septiana, 2013). Peralihan mata pencaharian tersebut terjadi beriringan dengan semakin sulitnya para nelayan tour guide memperoleh pendapatan. Hal tersebut terjadi akibat semua akses ke pulau ditutup dan penerapan PPKM oleh pemerintah.

Peralihan mata pencaharian tersebut dibagi menjadi dua yaitu peralihan pada mata pencaharian yang dahulu pernah mereka perjakan dan peralihan pada mata pencaharian yang baru mereka coba. Peralihan npada mata pencahrian yang dulu pernah mereka lakukan terdiri dari berjualan hasil kerajinan tenunan emas dan sulaman yang di pasarkan melalui media sosial dan berjualan ikan cupang menggunakan WhatsApp. Pekerjaan lain yang dijakdikan strategi oleh beberapa nelayan yaitu kehutan mencari kayu, menjaring ikan, berjualan dan berternak. (2) Melakukan pinjaman ke kerabat, Koperasi dan pemerintahan nagari. Pinjaman yang dilakukan nelayan tour guide terjalin dengan kerabat, lembaga Koperasi dan Pemerintah. Untuk mencukupi kebutuhan hidupnya, nelayan tour guide melakukan peminjaman dengan Kerabat terdekatnya, pinjaman itu dipergunakan untuk keperluan sehari-hari dan untuk modal membuka usaha baru.

Culture \& Society: Journal of Anthropological Research Vol. 3, No. 1, Th. 2021 
Sesuai dengan pernyataan informan yang melakukan pinjaman ke kerabatnya, sistem pengembalian yang dilakukan berupa uang dan jasa. Pinjaman tersebut dilakukan sebagai bentuk strategi untuk memenuhi kebutuhan di tengah masa pandemi Covid-19.

Beralih mata pencaharian merupakan sitem pengetahuan dan pengalaman yang dimiliki masyarakat dalam mengatasi masalah yang mereka hadapi. Peralihan dan perpindahan tersebut berupa peralihan pada pekerjaan yang dahulu mereka tekuni dan peralihan pada pekerjaan baru yang sekarang mereka lakukan. Dikarenakan pekerjaan utama nelayan sebagai tour guide dan seluruh pendapatan diperoleh dari pekerjaan tersebut, serta tidak adanya pekerjaan sampingan membuat nelayan tour guide beralih mata pencaharian. Peralihan tersebut terjadi memalui proses identifikasi terhadap masalah yang ada di lingkungan nelayan tour guide. peralihan terjadi karena adanya sistem pengetahuan yang didapat melalui pembelajar dan pengalaman nelayan tour guide. Sistem pengetahuan tersebut memunculkan tindakan-tindakan yang mereka percayai sebagai jalan keluar dalam menghadapi masalah. Pernyataan tersebut sejalan dengan teori etnosain oleh James P. Spradley menyatakan bahwa Ethnoscience adalah "system of knowledge and cognittion typical of given culture". Penekanannya di sini adalah pada sistem pengetahuan masyarakat, yang merupakan pengetahuan yang khas dari suatu masyarakat, dan berbeda dengan sistem pengetahuan masyarakat lain. Dengan kata lain etnosain secara emik menarik kesimpulan dari nelayan Tour Guide langsung terkait strategi yang mereka gunakan untuk memenuhi kebutuhan hidup sehar-sehari.

\section{Kesimpulan}

Berdasarkan hasil observasi dan wawancara yang dilakukan oleh peneliti di lapangan yang dilengkapi dengan data sekunder, maka diperoleh informasi yang menjelaskan bahwa: (1) Selama masa pandemi terjadi penurunan signifikan terhadap pendapatan nelayan tour guide di Desa Sungai Pisang. Secara garis besar terjadi penurunan sebesar 99\% dari pendapatan awal nelayan di Desa Sungai Pisang Kecamatan Bungus Teluk Kabung. (2) Dalam memenuhi kebutuhan hidup di tengah pandemi Covid-19 nelayan tour guide Sungai Pisang menerapkan 2 Strategi antara lain sebagai berikut: a. untuk memenuhi kebutuhan hidup dimasa pandemi Covid-19 nelayan melakukan berbagai macam pekerjaaan untuk memenuhi kebutuhan hidupnya. Beralih mata pencaharian merupakan strategi agar kebutuhan hidup nelayan terpenuhi. Peralihan tersebut dibagi menjadi peralihan pada mata pencaharian yang dulu pernah nelayan lakukan dan peralihan pada mata pencaharian yang baru nelayan tekuni. Nelayan yang beralih pada mata pencarian baru mereka tekuni umunya berkerja pada sektor online seperti berjualan Sulaman dan Tenunan online dan menjual Ikan Hias Online. b. Dalam upaya memenuhi kebutuhan hidup masyarakata nelayan melakukan pinjaman merupakan solusi agar mereka bisa memenuhi kebutuhan hidup.

\section{Daftar Pustaka}

Anggreini, L. (2015). Perjudian (Studi Sosiologi Tentang Perilakujudi Togel Di Kalangan Remaja Desa Mulyasari Kecemasan Sukamaju Kabupaten Luwu Utara). Psikologi Sosial, 2.

Asis, A. (2019). Strategi Bertahan Hidup Nelayan Karampuang Dalam Pemenuhan Kebutuhan Hidup. Schouler, 5(1), 133-145.

Ahimsa, H. (1985). Etnosains Dan Etnometodologi: Sebuah Pebandingan. Yogyakarta: Universitas Gajah Mada

Imron, M. (2003). Kemiskinan Dalam Masyarakat Nelayan. Jurnal Masyarakat Dan Budaya, 5(1), 63-82.

Jannah, M. (2016a). Pengetahuan dan Teknologi (Studi Kasus Nelayan Desa Jetis Kecamatan Nusawungu Kabupaten Cilacap) Skripsi. UNNES.

Culture \& Society: Journal of Anthropological Research Vol. 3, No. 1, Th. 2021 
Jannah, M. (2016b). Strategi Adaptasi Masyarakat Nelayan dalam Menghadapi Kemajuan Ilmu Pengetahuan Teknologi. Skripsi. Universitas Negeri Semarang.

Keesing, R. M. (2018). Teori-Teori Kebudayaan. Journal of Intellectual Property Rights, 23(4-5), 174-193.

Kristianti, K., Kusai, K., \& Bathara, L. (2014). Strategi Bertahan Hidup Nelayan Buruh di Desa Meskom Kecamatan Bengkalis Kabupaten Bengkalis Provinsi Riau. Berkala Perikanan Terubuk, 42(1), 62-68.

Lestari, Y., Hartati, S., \& Nopianti, H. (2019). Pemenuhan Kebutuhan Hidup Rumah Tangga Petani Miskin (Studi Kasus pada Petani Penggarap di Dusun II Talang Watas Desa Muara Langkap Kecamatan Bermani Ilir, Kabupaten Kepahiang). Jurnal Sosiologi Nusantara, 2(2), 94-103. https://doi.org/10.33369/jsn.2.2.94-103

Muhammad Natsir Kholis, Fraternesi, L. O. H. (2020). Dampak Prediksi Covid. Albacore 4(1), 111.

Septiana, T. C. (2013). Lesson Learned Peralihan Mata Pencaharian Masyarakat Sebagai Ketahanan Terhadap Perubahan Iklim Kelurahan Mangunharjo. Jurnal Wilayah Dan Lingkungan, 1(2), 123. https://doi.org/10.14710/jwl.1.2.123-140

Sudarsono, B. (2017). Memahami Dokumentasi. Acarya Pustaka, 3(1), 47. https://doi.org/10.23887/ap.v3i1.12735

Sugiyono, S. (2006). Metode Penelitian Kuantitatif. Bandung: Alfabeta.

Sugiyono, S. (2017). Metode Penelitian Kuantitatif, Kualitatif, R\&D. Bandung: Alfabeta.

Tiaranita, C. (2019). Faktor Peralihan Mata Pencarian Nelayan Tradisional Menjadi Penyedia Jasa Wisata Bahari (Studi Kasus Sungai Pisang Teluk Kabung Selatan Kecamatan Bungus Teluk Kabung Kota Padang). Disertasi. Universitas Andalas.

Winarno, K. (2015). Memahami Etnografi Ala Spradley. Smart. 1(2), 257-265. https://doi.org/10.18784/smart.v1i2.256 